\title{
THE DIFFUSION OF ORGANIZATIONAL REFORM IN DEVELOPING COUNTRIES: A CASE STUDY FROM INDIA ${ }^{1}$
}

Raphael Kaplinsky

\section{INTRODUCTION}

A number of Indian firms (both TNC subsidiaries and locally-owned enterprises) have made attempts to introduce new organizational techniques based largely upon Japanese experience. For example, a British TNC (Lucas PLC) has a subsidiary in South India manufacturing auto components and operating on an intra-plant Just-in-Time (JIT) schedule. Work-in-progress is 'pulled' between production points on ox-drawn carts using kanban cards, and cost-reduction and output enhancing characteristics have been significant. ${ }^{2}$ This Indian subsidiary is a relatively advanced adopter within the Lucas family and although much of its organizational change was stimulated by presentations made by Lucas Engineering and Systems and by visits paid to other affiliates, many of the changes are a product of the Indian affiliate's own efforts.

Crompton Greaves - whose experience with organizational change is described below and which is partly-owned by a British TNC - is one of about 30 Indian enterprises which had made substantial strides in introducing these techniques by 1991 . KKNohria, Chief Executive Officer of Crompton Greaves, estimates that although the firm has made considerable progress and stands at the leading edge of Indian best-practice, it represents approximately 'secondtier' United States performance with respect to organizational change and is a considerable distance behind Japanese practice. Most of these Indian enterprises have begin to introduce isolated elements of organizational reform in recent years. Unfortunately there are no detailed accounts weighing up the overall costs and benefits of these innovations. The case-study which follows provides some evidence of overall corporate restructuring, as well as showing the progress made in a large plant. However the data available does not make it possi-

\footnotetext{
1 This case-study is drawn from UNCTC (1993) which includes case studies of organizational changein a number of industrially developed and less developed countries.

2 For more discussion of the details of JIT, kanban, and other instruments of organizational change in production, see Bessant (1991), Kaplinsky (1991), Monden (1983) and UNCTC (1993). See
}

ble to evaluate the net financial and economic benefits of these organizational reforms.

\section{CROMPTON GREAVES LTD ${ }^{3}$}

\subsection{Corporate Background}

Crompton Greaves Ltd (hereafter CGL) was incorporated in 1937 as a private company, being a whollyowned subsidiary of a British company. By 199037.5 per cent of CGL equity was owned (through an affiliate) by Hawker Siddley of the United Kingdom, and a further 37.5 per cent by a locally-owned Indian firm (which is part of the Thapar Group); 12 per cent of equity is owned by financial institutions and the remaining 13 per cent by 6,000 shareholders. Management has always been - and continues to be largely independent of any of these major shareholders. Thus, although formally a subsidiary of a British TNC, CGL operates largely as a locallyowned company, except for policies on dividends and major strategic expansions and acquisitions.

CGL is a large, diversified engineering firm, predominantly focused on the electrical products sectors. In 1991 there were approximately 8,500 employees, and CGL's turnover exceeded Rs $500 \mathrm{~m}$ crore (equivalent to $\$ 300 \mathrm{~m}$ ). In $1985 \mathrm{CGL}$ was estimated to be the 54th largest non-state owned firm in India.

By the early 1980s CGL was experiencing a considerable squeeze on pre-tax profits, which fell from more than Rs12m crore on a turnover of approximately Rs180m crore in 1981 to around Rs $2 \mathrm{~m}$ crore on a turnover of approximately Rs $190 \mathrm{~m}$ crore in 1984. Its equity price performance on the stock exchange was considerably worse than that of the all-industry index, as well as the electrical/electronic sub-sector. Given the rate of inflation in India

also the Appendix to the Introduction to this Bulletin for a brief definition of such terms.

3 Data on CGL's operations were obtained through interviews and from a Harvard Business School case-study (Nohria and Gladstone 1991). Thanks are due to Kewal Krishan Nohria for his cooperation with this research. 
in the early 1980s, real revenue had been falling throughout the first half of the decade.

\subsection{The Restructuring Strategy}

In this context of declining profitability and growth Kewal Krishan Nohria (hereafter KKN) was appointed Managing Director in 1985. KKN had visited Japan on a JUSE (Japanese Union of Scientists and Engineers) sponsored tour in the early 1980s and had become a convert to the organizational technologies encompassed within the JIT and TQC procedures. He diagnosed CGL as suffering from two major problems. The first was its predominant location around Bombay, where the rate of inflation of around 15 per cent was consistently greater than that of all-India (around 10-12 per cent). But secondly, and more importantly, market conditions were mirroring those experienced by many industrially advanced country firms in their global operations at around the same time - buyers were becoming much more discerning, and supplier firms were finding it more difficult to dictate prices and market performance criteria (such as delivery schedules and costs).

CGL responded by redefining its corporate goals to increase growth and profitability without increasing borrowing or the number of employees. A series of growth targets were set:

double turnover every four years

- establishment of a new plant (preferably outside of Bombay) every three months

- 10 per cent of sales each year to come from new products

- one quarter of all products to be replaced every three years.

The profitability target (pre-tax profit as a percentage of sales) was set at 4 per cent by 1990 and $6-7$ per cent by 1995-96 - compared with a rate of around 2 per cent in 1988 (and half that in 1985).

These objectives were to be met by restructuring in five areas:

greater concern for customers

greater concern for employees

- improvement in product quality and delivery

- reduction in costs
- introduction of new products and the diversification into new electrical-related areas.

KKN's primary implement for achieving these ends was to refocus its relationship with (and between) its employees and to engage in a fundamental process of micro-level organizational reform. Significantly, no extensive diffusion of electronics-based automation has occurred in CGL.

\subsection{Redefining the Relationship with and between Employees}

KKN began by visiting all of CGL's divisions and regional offices. Open discussions were held with many employees in groups of 40 . In the first year 1,000 employees (over 10 per cent of the total labour force) met KKN in this way. Managers were expected to replicate this process of open discussion throughout the firm. This represented a considerable shift from past practice in what had previously been a hierarchically organized firm of 25 product divisions, with centralized marketing, finance, human resource and administrative controls, overlain with four regional geographical divisions. The Southern Region General Manager described this process as:

...the first time that we were collectively able to focus on what the customer wanted and what we as a firm had to do. Everyone - from the engineer to the general manager who has to deal with the customers and the dealers - was able to communicate face-to-face as opposed to through reports. These open-houses were not one-sided affairs. Everyone joined in the discussion. This had two effects. First, people realized that top management is approachable: and second, they also realized that the top management had a clear point-of-view and vision of where we needed to go.

(Cited in Nohria and Gladstone 1991: 4)

From these visits came CGL's Mission Statement 'Excellence through a Concern for QPCE - Quality, Productivity, Cost and Employees'. Managerial responsibility was devolved to a much lower level than previously. KKN's intent was to induce managers to 'own responsibility' for overall operating performance. Hence previous categories of 'cost centres' and 'profit centres' were abolished and the concept of 'performance centres' was introduced. Performance in this case was to be measured by a 
broader set of objectives, namely pre-tax profit, revenues and revenue growth, cash-flow, manpower and capital expenditure.

Perhaps more significantly, KKN tackled directly the problem of continuous improvement which is one of the most significant organizational innovations stemming from Japan. The focus was on instituting a process in which continual incremental improvement would become routine. To ensure this goals were set in relation to three measurable parameters: quality, productivity and cost.

Quality was defined in terms of:

number of customer returns and complaints

the rejection rate of defective products in testing

in-process rejection rates

rejection rates for incoming components.

In production, the quality-target was to achieve Japanese 'zero-defect' practice. But recognizing the large amount of ground to be made-up, a gradual process of halving the target each year was adopted. In marketing the quality target was to reduce service-visits from a delay of 10-15 days (after the initial request) to two-three days.

Productivity was defined in relation to sales per employee. KKN pointed out to employees that whereas these averaged $\$ 100,000$ /employee in the United States in the same sector, the 1988 rate for CGL was only $\$ 20,000 /$ employee. A target of $\$ 50,000 /$ employee was adopted.

The final tool for achieving continuous improvement was cost reduction. Managers were given the task of preparing annual budgets which included a number of detailed elements. They were expected to meet a continually moving target for cost reductions.

Two other important elements were included in this redefinition of human resource management in CGL. The first of these was a strong emphasis given to team-work. An 'involvement index' was developed to measure employees' participation in small group activities. Targets for 1995 were set: 100 per cent involvement of senior management, $40-50$ per cent for white collar workers and 30 per cent for the bluecollar workforce. Small groups varied in nature, including quality circles, value added management groups and materials management groups. These were introduced company-wide and were accompanied by firm-wide conferences. ${ }^{4}$ These smallgroups had the effect of promoting continuous improvement through peer group pressure. KKN observed that:

People will work as hard as they can. They are driven toward being the most they can be. Moreover, people like to test themselves in a community of peers. They often don't mind failing in the presence of their boss, but do mind in the presence of their peers.

(Nohria and Gladstone 1991: 9)

The effectiveness of this strategy was reflected by one manager in his discussion of the effectiveness of these meetings:

Every three months all of us can see crystal clear how good we each are at meeting our commitments. Though we are not pressurized by KKN, none of us want to admit that we have failed. Right now, I am failing at my budgets, so I am shuddering about the April meeting. I am already working hard to make sure that I meet my commitments in the July meeting. What all of us want is to be able to strut into that meeting as opposed to slinking out of it.

(Nohria and Gladstone 1991: 9)

A second important element of human resource development concerned training. An aggregate 'training exposure rate' was set, defined as the number of people in training courses during the year divided by the total number of employees. A target rate of three was set for 1990. Aiming at Japanese best-practice, a target was also set of one per cent of all employees being involved as internal trainers. By 199185 per cent of the firm's 1,000 managers, 50-60 per cent of its white-collar workers and 40 per cent of the direct workforce had received at least 15 days of training per year, Within this training of the direct workforce, attention was given to the multi-skilling necessary for achieving flexibility. Total investment in formal training was approximately one per cent of turnover in 1990, with an equivalent sum given over to on-the-job-training activities.
${ }^{4}$ For example, in-house conventions were held annually on a range of subjects, including on Technology, Materials Management and
Quality Circles. Each was accompanied by its own publication. 


\subsection{Implementing Organizational Reform: The Experience of the Ahmednagar Plant}

The competitive impact of these organizational changes on CGL's performance has been significant. Labour productivity has increased enormously. Between 1980 and 1990, output in real terms rose by 35 per cent, while employment fell by 15 per cent. By 1990 six per cent of revenue came from new products and 14 per cent of products had been replaced in the previous three years. Sales rose markedly after this organizational reform, as did profits and dividends (Figures 1 and 2). By 1990 CGL had risen to become India's 28th largest non state owned firm (compared to a ranking of 54 in 1985).

This turnaround is accounted for by changes in corporate level structures and incentives to achieve KKN's goal of QPCE - quality, productivity, cost and employees. ${ }^{5}$ They found their reflection at the plant level where a raft of organizational changes were introduced including cellular production, JIT production and TQC procedures.

The Ahmednagar plant, manufacturing motors and components, is representative of overall progress throughout the corporation. Changes in organization were introduced early in 1987 with the goal of:

Continual Improvement in Manufacturing through the Progressive Elimination of all Non Value Adding Wastes with the Total Creative Involvement of all Employees (Emphasis in original.)

(Taken from Ahmednagar plant document.)

The changes were introduced first through the reduction of stocks of raw materials, WIP and finished goods, then the reduction of throughput time for motor components, ${ }^{6}$ the pursuit of the single-minute exchange of dies (SMED), reductions in lot sizes, 'fool-proofing' - (making it impossible to make mistakes, 'poka yoke'), waste elimination, group work, and zero defect procedures.

There were 561 employees at the Ahmednagar plant in 1991, of whom 379 were direct production workers, 135 were white collar staff and the remainder were management. Whereas the 'employer involvement index' in group activities for CGL as a whole for 1995 was 100 per cent for management, $40-50$ per

${ }^{5}$ Note that enhanced wages and bonuses were not used to motivate participation. CGLsalaries and wages were not out-of-line with the industry average.
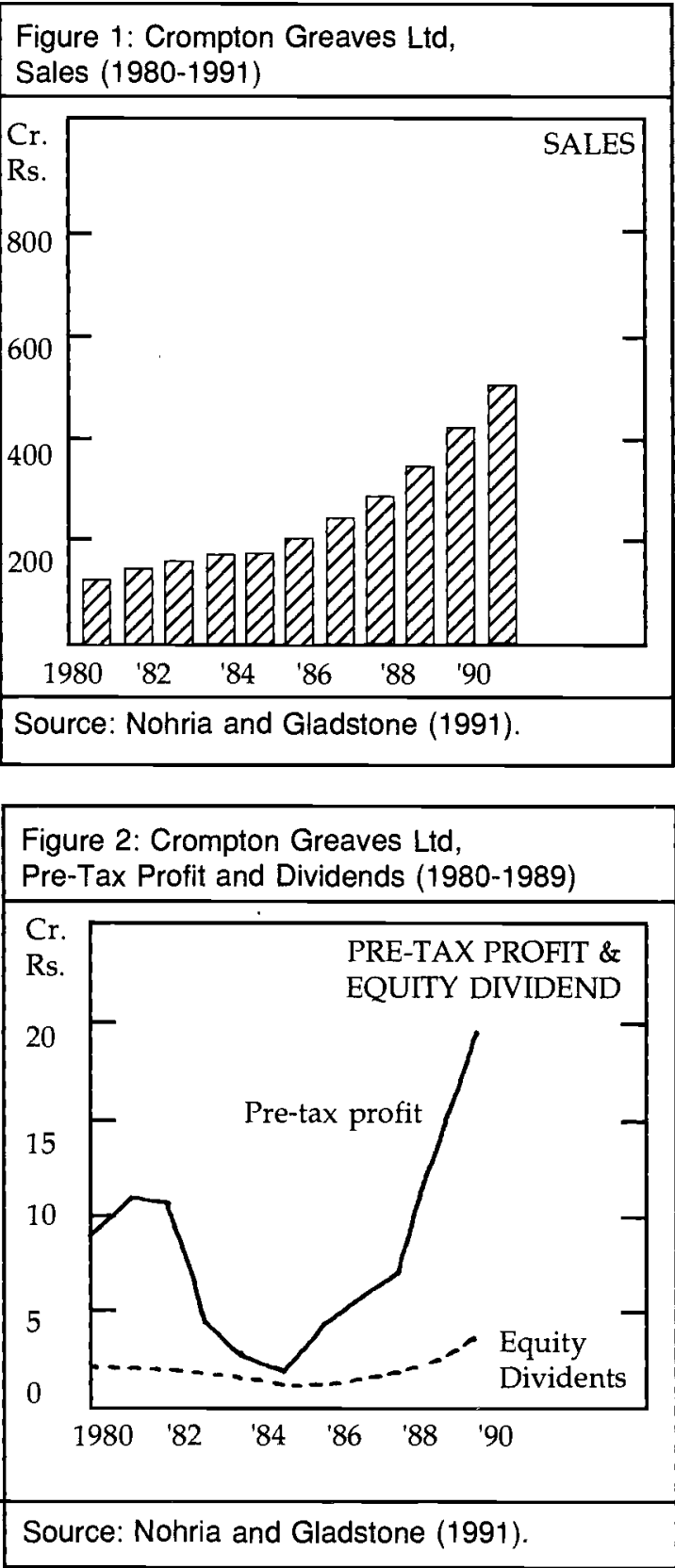

cent for white-collar staff and 30 per cent for bluecollar staff, the actual recorded levels at the Ahmednagar plant in 1990 were 100 per cent, 80 per cent and 20 per cent; so by this measure, Ahmednagar was a considerable way down the targeted path.

\footnotetext{
6 Throughput time measures the period between raw materials/ components entering the production stage and then emerging at the end of the line.
} 
Table 1 provides data of operational changes at some major work-points in this plant. As can be seen, throughput time declined significantly in all cases by a factor of more than three times. The value added time (that is, the proportion of time a component was on the shop floor it was having value added to it) rose by similar ratios. These measures reflect greatly improved flow of products. Since flexible production requires frequent changeover of machinery, a key requirement for cost-effective flexible production is a reduction in machine setting time, and an increase in the frequency of machine setting. Table 1 shows significant reductions in set-up time and the number of settings per month had also increased. Consequently, batch sizes have fallen sharply (as shown in the table), and this reflects the drive for more flexible production and smaller inventories. Although there is only limited information available, the distance travelled by parts before and after reorganization and the time spent waiting for missing components have also improved substantially.
Inventory levels fell appreciably as a result of these organizational changes, as shown in Figure 3. The average days of stock held fell between July 1986 and July 1988 from 85 days to less than 30 days for finished goods, and from around 50 days to less than 30 days for WIP and raw materials. Peak levels of stock each year fell in similar proportions. Whilst these are significant falls, stocks are still higher than those achieved by many enterprises in the industrially advanced economies - in Japan, for example, total stocks in the automobile industry account for only three days production.

The ability to produce with greater flexibility is reflected in a greatly improved delivery performance. Overdue deliveries were virtually eliminated, falling from a high point of 300 motors before reorganization, to under 10 in 1989.

The link between zero-defects in the manufacturing process and the introduction of quality-at-source procedures in one production cell (casting) is shown

Table 1: CGL Impacts of Organizational Change, Ahmednagar Plant

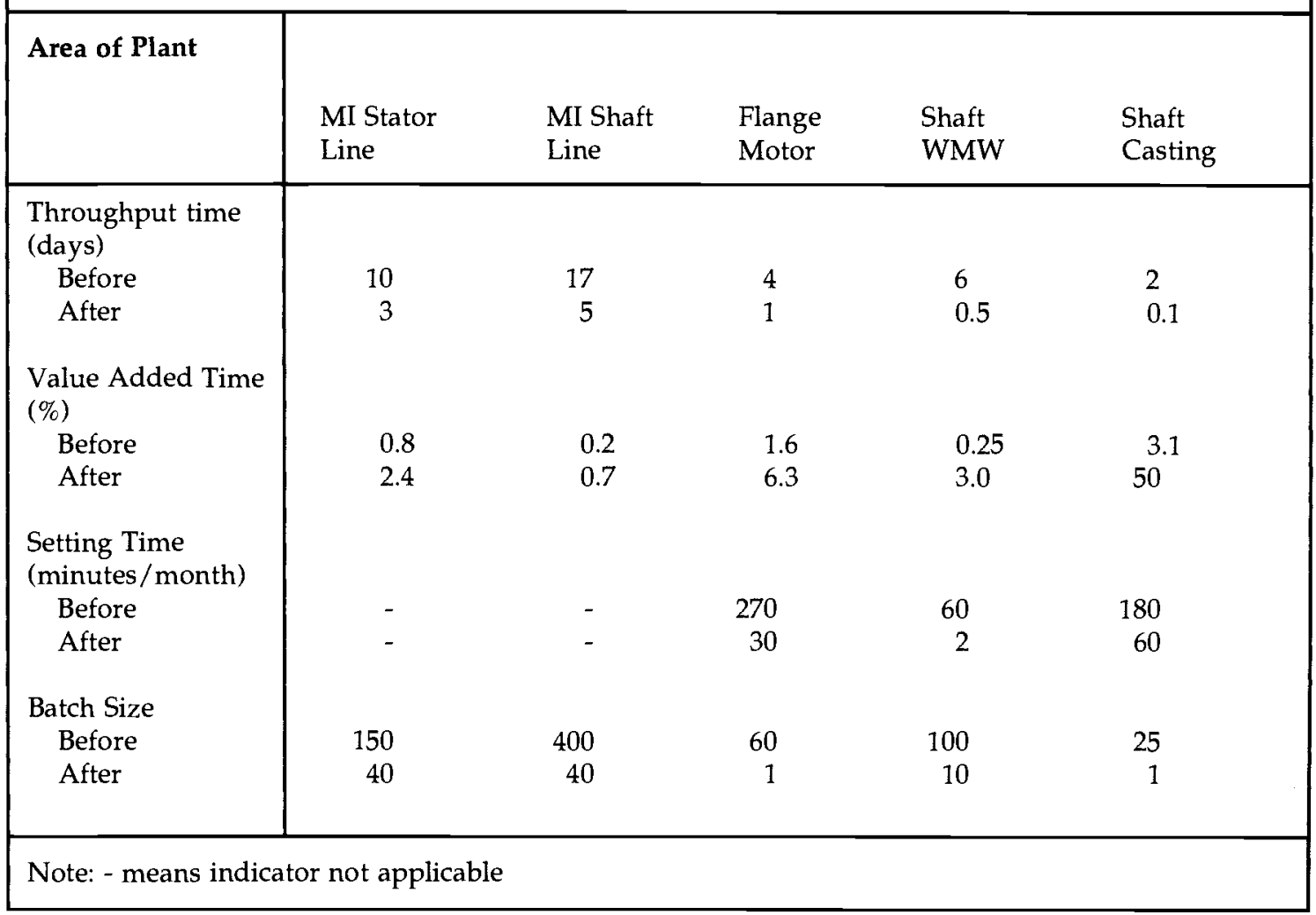




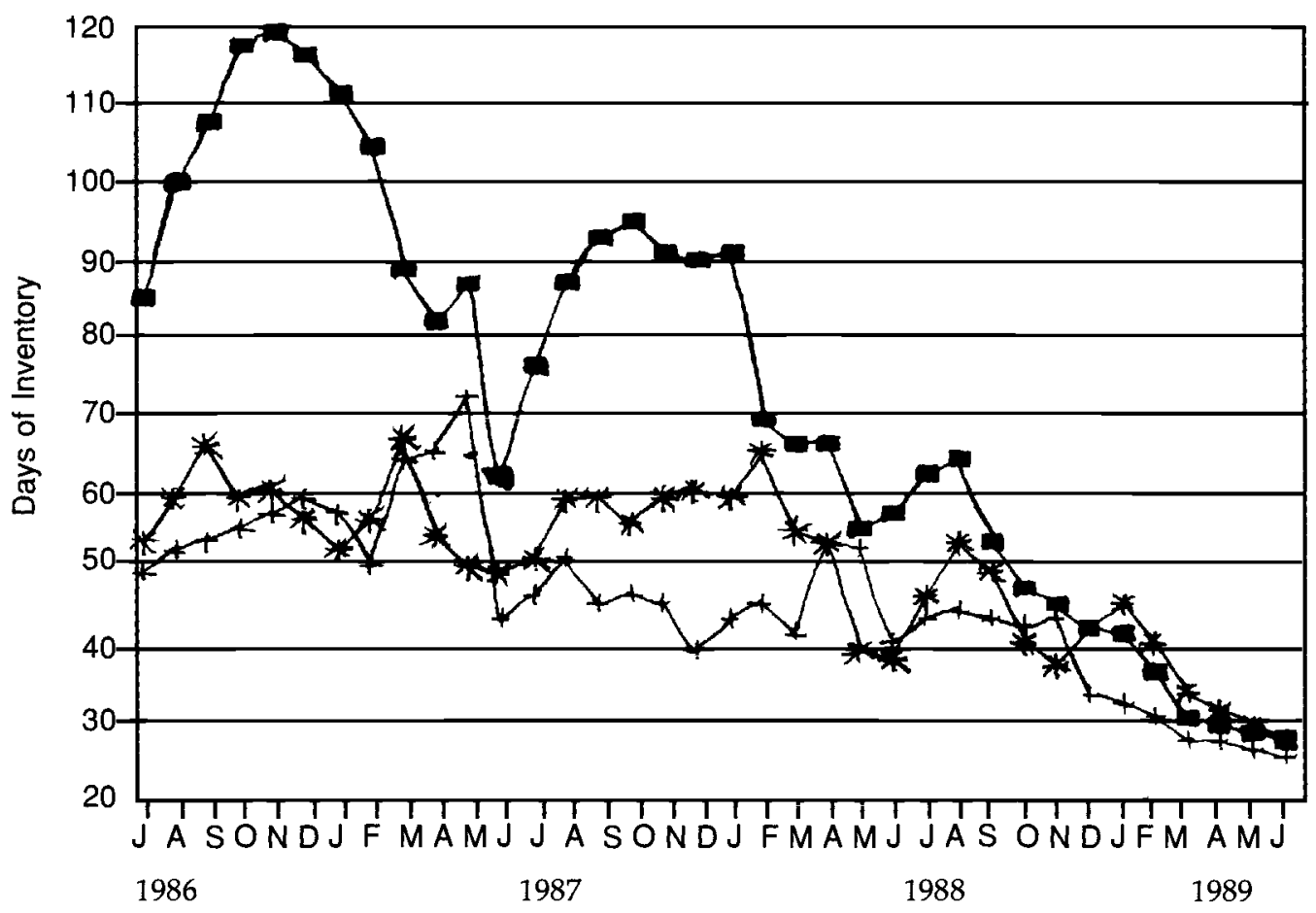

$\rightarrow$ Finished Goods

in Figure 4. The greater the number of TQC operators the lower the level of defective production. In the winding section, the percentage of defects fell from 4.3 per cent in 1983-4 to virtually nothing after the reorganization in 1987. The number of quality circles in the Ahmednagar plant grew in tandem with those in CGL as a whole. By September 1989 there were 122 circles in CGL, with a membership of 1,252 (equivalent to 15 per cent of total employees) and more than 20 per cent of all blue-collar workers.

\subsection{Ownership-Relations and the Introduction of Organizational Change in CGL}

The turnaround in profitability and sales in CGL is closely linked with the decision to invest in its labour force and to introduce many elements of the new organizational techniques in its plants. Given that the joint-largest shareholder of CGL was a British TNC (holding 37.5 per cent of the equity) one issue at stake is whether this ownership-relation partly explains CGL's pioneering adoption of organizational reform in India. It is instructive to bear in mind here that another Indian plant recognized as a role-model for much of local industry (Brakes India) is a subsidiary of a large British TNC (Lucas) and has been actively assisted by organizational advice provided by a restructuring affiliate and by visits paid by Indian management to foreign affiliates introducing organizational reform.

There is no evidence, however, that either the introduction of organizational reform or its extension through the various CGL plants was in any way stimulated or sustained through linkages with the United Kingdom parent. It appears, rather, that the stimulus to change came from a visit paid by the CEO to Japan in the early 1980 s and by his personal commitment to the implementation and extension of organizational reform throughout the enterprise. 
Figure 4: Crompton Greaves Ltd, Scrap and Zero Defect Operators at Ahmednagar Plant

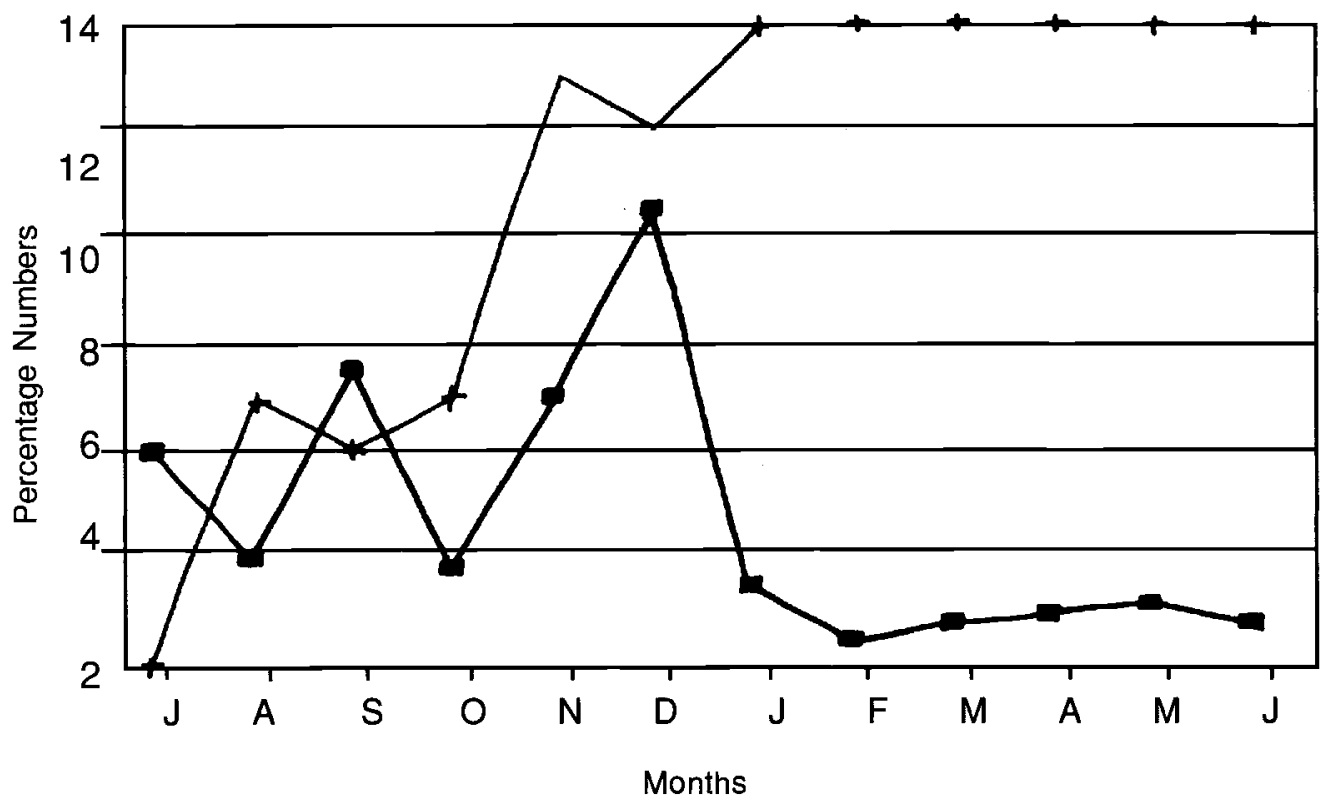

$\rightarrow-$ Percentage Scrap $\quad+$ Zero Defect Workers

At no stage is there any evidence that this process was enhanced (or, conversely, held back) by links with CGL's British parent, which was content for the Indian management to operate plants in the way it saw fit; the consequent growth of sales and profits only served to reinforce this hands-off strategy by Hawker Siddley to its Indian subsidiary.

\section{CONCLUSIONS}

This brief case-study of organizational reform in CGL shows that there is scope for considerable progress, even in an LDC which has poor economic infrastructure and in which supplier firms are often weak by international standards. Two major conclusions can be drawn from this experience. First, the barriers to entry do not appear to be insurmountable. Even though India has a relatively well-educated population, levels of literacy on the shop floor at CGL and at other implementing enterprises are not high. And, second, CGL's progress does not appear to arise from the introduction of costly and capital-intensive equipment, but rather from its attention to its human resources, its factory layout and to new principles of production engineering. Both of these conclusions are corroborated by other case studies drawn from India (UNCTC 1993) as well as those drawn from Zimbabwe (Kaplinsky and Posthuma 1993, and Posthuma in this Bulletin).

The impact of these changes on CGL's turnover, profitability and corporate ranking are high. It might be expected therefore that the diffusion of these techniques will be very rapid in LDCs. However, as in the case of the industrially advanced areas, market failure is prevalent in the diffusion of new forms of behaviour and organization. There is thus a clear case for sensitively-attuned government assistance to the productive sector. 


\section{REFERENCES}

Bessant, J., 1991, Managing Advanced Manufacturing Technology, London: Hutchinson

Kaplinsky, R., 1991, 'From mass production to flexible specialization: a case-study from a semi-industrialised economy', Discussion Paper No 295, University of Sussex, Brighton: Institute of Development Studies

Kaplinsky, R. and Posthuma, A., 1993, 'Organizational change in Zimbabwe's manufacturing sector', Report Prepared for United Nations University (INTECH) University of Sussex, Brighton: Institute of Development Studies
Monden, Y., 1983, Toyota Production System: Practical Approach to Production Management, Atlanta: Industrial Engineering and Management Press

Nohria N., and Gladstone, J., 1991, 'Compton Greaves Ltd', Case Study N9-491-074, Boston: Harvard Business School

UNCTC, 1993, Transnational corporations and the transfer of new management practices to developing countries', forthcoming 